University of Nebraska - Lincoln

DigitalCommons@University of Nebraska - Lincoln

USDA Forest Service / UNL Faculty Publications U.S. Department of Agriculture: Forest Service -National Agroforestry Center

2007

Seedling Establishment and Survival on Restored Campsites in Subalpine Forest

David N. Cole

Follow this and additional works at: https://digitalcommons.unl.edu/usdafsfacpub

Part of the Forest Sciences Commons

Cole, David N., "Seedling Establishment and Survival on Restored Campsites in Subalpine Forest" (2007). USDA Forest Service / UNL Faculty Publications. 60.

https://digitalcommons.unl.edu/usdafsfacpub/60

This Article is brought to you for free and open access by the U.S. Department of Agriculture: Forest Service -National Agroforestry Center at DigitalCommons@University of Nebraska - Lincoln. It has been accepted for inclusion in USDA Forest Service / UNL Faculty Publications by an authorized administrator of DigitalCommons@University of Nebraska - Lincoln. 


\title{
Seedling Establishment and Survival on Restored Campsites in Subalpine Forest
}

\author{
David N. Cole ${ }^{1,2}$
}

\begin{abstract}
This study experimented with common restoration techniques (scarification, soil amendments, mulch, and seeding) on six closed wilderness campsites in subalpine forests in Oregon. Effectiveness in encouraging seedling establishment, growth, and survival was assessed every year for the first 7 years following treatment. Closure and restoration of the campsites increased the density of plants established from seed. Despite an original density of virtually zero, mean density of perennial plants was 55 plants $/ \mathrm{m}^{2} 7$ years after closure. All the treatments, with the exception of the biodegradable mulch mat, increased plant density. Seven years after treatment, seeding had increased plant density 5-fold, whereas scarification and soil amendments (organic matter, compost, and soil inoculum) had each increased
\end{abstract}

density 3-fold. The organic and compost amendments also had the positive benefit of increasing growth rates and shortening the time-to-reproductive maturity. Results suggest that restoration of the herbaceous cover on these campsites can occur rapidly using the techniques employed. All but one of the species we seeded established in substantial quantities and survived at densities exceeding their density in the naturally sparse herbaceous cover on these sites. Thirty-six perennial species volunteered on these sites. The remaining challenge is reestablishment of the shrub species that comprise much of the ground cover in these forests. These species seldom establish from seed.

Key words: compost, recreation impacts, scarification, seeding, soil amendments.

\section{Introduction}

Ecological restoration of recreation impact in highelevation-protected areas has received little attention. This is unfortunate because recreation can damage vegetation and soil on campgrounds and other nodes of concentrated use, compromising preservation goals of protected areas. Protected area managers attempt to close and restore damaged recreation sites, often with little success (Moritsch \& Muir 1993). Restoration of impacts can be unusually challenging, given the remoteness of sites, unfavorable growing conditions (e.g., short growing seasons, shallow soils), and high standards for success (restoration of natural conditions).

Although there has been substantial research on effectiveness of such restoration treatments as seeding, soil amendments, and mulches, little of this research has been conducted in subalpine ecosystems or on damaged recreation sites. Success with seeding of native species, particularly grasses, has been reported in alpine ecosystems (Chambers et al. 1988; Smyth 1997). Mulching has been found to increase seeding success at high elevations (Petersen et al. 2004). Seedling growth has been reported to be greater on organic topsoil than on mineral soil (Chambers et al. 1990), leading to recommendations that

\footnotetext{
${ }^{1}$ Aldo Leopold Wilderness Research Institute, Forest Service, Rocky Mountain Research Station, 790 East Beckwith Street, Missoula, MT 59801, U.S.A.

${ }^{2}$ Address correspondence to D. N. Cole, email dcole@fs.fed.us

(C) Journal compilation (c) 2007 Society for Ecological Restoration International No claim to original US government works
}

organic amendments be used in alpine restoration (Chambers 1997). However, students of high elevation restoration consistently note that seedling establishment and survival vary greatly with disturbance characteristics and species life history, making it difficult to extrapolate results from one situation to another (Urbanska \& Schütz 1986; Chambers et al. 1990).

Given the paucity of restoration research in subalpine ecosystems and on recreation sites, this study experimented with restoration treatments on long-disturbed campsites in subalpine forests. It was conducted in a designated Wilderness, where management objectives stress preservation of natural conditions and minimal manipulation. Consequently, commonly recommended treatments compatible with these objectives were selected. Specifically, the effectiveness of seeding; improving the physical, biological, and chemical properties of soils (through scarification and amendments of organic matter, compost, and soil inoculum); and ameliorating microclimatic conditions (through application of a biodegradable mulch mat) were assessed over a 7-year period.

\section{Methods}

\section{Study Sites}

The study was conducted on six campsites in the Eagle Cap Wilderness, Wallowa Mountains, northeastern Oregon. These campsites have been highly disturbed for a long time, probably more than 50 years. Compared to adjacent 
undisturbed sites, campsites have lost most of their vegetation and organic soil horizons (Cole \& Fichtler 1983). Mineral soils are highly compacted and have substantially reduced mineralizable $\mathrm{N}$ and microbial activity (Zabinski et al. 2002). The campsites are all located at an elevation of 2,215-2,300 m, adjacent to subalpine lakes that are accessible only on foot or horseback (12-15 km from the closest road). All sites are in forests with an overstory of Subalpine fir (Abies lasiocarpa), Lodgepole pine (Pinus contorta), and Whitebark pine (Pi. albicaulis). The most abundant plants in the understory are ericaceous shrubs, Grouse whortleberry (Vaccinium scoparium) and Red heather (Phyllodoce empetriformis), and caespitose graminoids, Ross' sedge (Carex rossii) and Parry's rush (Juncus parryi). Soils are shallow, sandy, acidic ( $\mathrm{pH} 4.2-4.8)$, and derived from granitic substrates (Cryochrepts and Cryorthents). Winter snowfall at these elevations is typically heavy. After snowmelt, which typically occurs in early July, summers are typically hot and dry.

\section{Design and Treatments}

A three-factor experiment, using a split-plot design, was employed. In August 1995, the six campsites were closed to recreation use (with rope and closure signs), and 12 treatment plots $(1.5 \times 1.5 \mathrm{~m})$ were established on each campsite. The soil was scarified on these plots. Shovels, picks, hoes, and hand-kneading were used to break up compaction and clods to produce a crumb texture to a depth of $15 \mathrm{~cm}$. Because the minimum treatment in the experiment included soil scarification, an additional plot (not treated in any way) was established within the closed area but on a part of the campsite that was not scarified. This control plot was used in an analysis, separate from the factorial experiment, of the effect of scarification in the absence of mulch, soil amendments, and planting.

Of the three factors in the split-plot experiment, mulch was the factor used to establish the whole-plot units because it was most feasible to apply the mulch blanket over large areas. Six contiguous plots on each site were covered with a biodegradable mulch mat of straw interwoven with cotton string and jute (North American Green, Evansville, IL, U.S.A.). The other six contiguous plots were not mulched. Within each of the two mulch whole plots, three levels of soil amendment and two levels of planting were assigned to split-plot units in a completely random design. Each combination of soil amendment and planting occurred in each whole plot. Figure 1 illustrates the layout for one of the campsites. Each campsite had a unique ordering of treatments, within the mulch whole plots. On three of the campsites, the contiguousness of plots was interrupted by several tree boles or rock outcrops. Each of the six campsites provided one of six replicates.

There were three levels of soil amendment. Within each whole plot, two treatment plots (split-plot units) received no amendments. Another two were amended with organic matter and inoculated with native soil from the rooting zone of transplants. The organic matter was a $2.5-\mathrm{cm}$ layer of locally collected, well-decomposed organic matter supplemented with peat moss (approximately 20\% peat moss), mixed into mineral soil to a depth of $7.5 \mathrm{~cm}$. The final two plots were amended with compost in addition to the organic matter and inoculum treatment. A $2.5-\mathrm{cm}$ layer of sewage sludge and log yard waste compost with a C:N ratio of approximately 20:1 (EkoCompost, Missoula, MT, U.S.A.) was raked into the top $10 \mathrm{~cm}$ of soil.

The two levels of planting were planted and not planted. Within each whole plot, three plots were planted and three were not. Planted plots were both seeded and transplanted. Six transplants (mean diameter of $15 \mathrm{~cm}$ ) per planted plot were excavated from undisturbed, mature vegetation, close to the campsites. The response of these transplants to treatment is reported in Cole and Spildie (2006).

Seeds were locally collected and immediately broadcast on the planted plots. This made it impossible to test the viability of the seed. The species seeded on each site differed due to environmental variation among campsites and available species with mature seed. One site was not seeded at all because there was no ripe seed in the vicinity. Parry's rush (Juncus parryi) and Alpine timothy (Phleum alpinum) were seeded on three campsites, and Alpine pussytoes (Antennaria alpina), Woolly pussytoes (An. lanata), Alpine aster (Aster alpigenus), and Creeping sibbaldia (Sibbaldia procumbens) were seeded on two sites. Timber oatgrass (Danthonia intermedia), Globe penstemon (Penstemon globosus), and Bottlebrush squirreltail (Sitanion

\begin{tabular}{|c|c|c|c|c|c|c|}
\hline 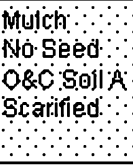 & 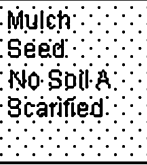 & 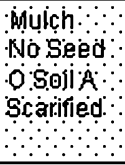 & $\begin{array}{l}\text { Murch } \\
\text { No Seed } \\
\text { scarified } \\
\therefore \therefore \therefore\end{array}$ & 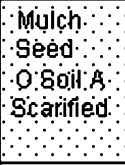 & 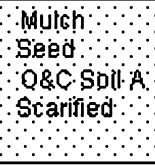 & $\begin{array}{l}\text { No Mulch } \\
\text { No Seed } \\
\text { No Soil A }\end{array}$ \\
\hline $\begin{array}{l}\text { No Mulch } \\
\text { Seed } \\
\text { No Soil A } \\
\text { Scarified }\end{array}$ & $\begin{array}{l}\text { No Mulch } \\
\text { Seed } \\
\text { O\&C Soil A } \\
\text { Scarified }\end{array}$ & $\begin{array}{l}\text { No Mulch } \\
\text { Seed } \\
\text { O Soil A } \\
\text { Scarified }\end{array}$ & $\begin{array}{l}\text { No Mulch } \\
\text { No Seed } \\
\text { No Soil A } \\
\text { Scarified }\end{array}$ & $\begin{array}{l}\text { No Mulch } \\
\text { No Seed } \\
\text { O Soil A } \\
\text { Scarified }\end{array}$ & $\begin{array}{l}\text { No Mulch } \\
\text { No Seed } \\
\text { O\&C Soil A } \\
\text { Scarified }\end{array}$ & No Scarif \\
\hline
\end{tabular}

Figure 1. Distribution of treatments for one campsite, illustrating completely random assignment of treatments within mulch whole-plot units, as well as the separate nonscarified control. Treatments are the following: mulch or no mulch; seed or no seed; no soil amendment, organics amendment, or organics and compost amendment; and scarified or not scarified. 
hystrix) were seeded on one site. Nomenclature follows Hitchcock and Cronquist (1973).

The quantity of seed varied among species and therefore among campsites. Due to time constraints (an approaching end-of-season storm), the quantity of seed was not precisely measured. Consequently, the absolute density of seeded species and variation in seed density among campsites are of little interest. Density would presumably be quite different if more or less seed had been sown. Of primary interest was variation among treatments, and for this purpose, equal amounts of seed of the same species were sowed on each planted plot within a site.

Reports from earlier campsite restoration projects in the Pacific Northwest indicated that it is common for most seedlings to die during prolonged periods of summer drought (Lester 1990). To ensure against this, plots were given supplemental water during the first summer following treatment. Each plot (planted and unplanted) was given $2 \mathrm{~L}$ of water thrice that summer, when the soil appeared to be extremely dry.

\section{Measurements and Data Analysis}

Starting in 1996, plants that had established from seed were recorded, by species, in a 1-m square quadrat located in the center of each plot. If the plant had flowered, this was noted. On a few plots, plants were so dense that they were recorded in a smaller $40 \times 40-\mathrm{cm}$ subplot. In 1996 and 1997, seedling establishment was assessed every 2 weeks starting in early July (four times). All established seedlings were counted, and a colored toothpick was placed next to each seedling to denote date of establishment. This made it possible to assess within- and betweenyear mortality. In 1998, plants were counted twice but were not mapped. Due to time constraints, from 1999 to 2002, plants that had established from seed since the start of the experiment were counted once, in September, at the end of the growing season.

I attempted to distinguish the response of seeded plants from that of volunteers (plants that germinated from seed in the existing soil seed bank or from seed that dispersed naturally onto the site). On seeded plots, distinguishing seeded plants from volunteers was impossible for seeded species. On seeded plots, I assumed that only seedlings of species that were not seeded were volunteers. The lack of volunteers of seeded species on unseeded plots (except for a few, e.g., An. alpina and $J$. parryi) suggests that this assumption was generally valid.

Accurately counting individuals in clumps was occasionally difficult for Ph. alpinum and An. alpina. This may have resulted in some overestimation of density. It was also not possible to determine, for shrubs, whether newly emerged shoots had germinated from seed or sprouted from roots. It is likely that most of the shrub "seedlings" represent vegetative rather than sexual reproduction.

In each seeded plot, the height of 10 randomly selected individuals of a seeded species was measured each year.
In 1996 and 1997, four individuals of the seeded species were excavated and root and shoot biomass measured.

For each response variable, repeated measures analyses of variance (ANOVAs), appropriate for split-plot designs, were performed (using an autoregressive covariance structure, PROC MIXED in SAS 9.1). Data were log transformed when they were not normally distributed and transformation resulted in a close approximation of normality. Heterogeneity of variance was generally not a problem, before or after transformation. Most data required transformation. For the three-factor experiment, treatment effects (mulch, soil amendments, and planting) often varied significantly with time since treatment (i.e., interactions with time were significant). For the separate analysis of scarification effects, treatment did not vary significantly with time. In cases where variation with time was significant, treatment effects are described for each of the 7 years of the experiment, but the significance of effects was only assessed at the end of the experiment, in 2002. In those cases where treatment interactions with time were not significant, results of the repeated measures analyses are reported.

The power of statistical tests was low because sample size was small (six replicate campsites), environmental conditions on the campsites were variable, and both the species seeded and those that volunteered varied somewhat among sites. Statistical power was conserved using one-tailed tests of a few primary hypotheses (as opposed to evaluating all possible multiple comparisons). To assess the hypothesis that scarification has positive effects, the control (the plot that was not even scarified) was compared to the one plot on each campsite that was scarified but was not mulched, amended, or planted. For the three factors included in the split-plot design (mulch, soil amendment, and planting), main effects of each factor and interactions between factors were assessed. Interactions between these factors were never statistically significant. To test hypotheses that planting and mulch (each of which had two levels) have positive effects, overall one-tailed $F$ tests are reported for each factor. To evaluate whether soil amendments had a positive effect, Dunnett's tests adjusted for multiple comparisons were used to compare the no-amendment treatment to the organics-only treatment and to compare the no-amendment treatment to the organics and compost treatment. This is the most powerful test of differences between treatments and a "control" that still controls experiment-wise error. To assess whether the organics and compost amendment was more effective than the organics-only amendment, less powerful one-tailed Tukey's tests, again adjusted for multiple comparisons, were used.

\section{Climatic Patterns}

Although there was yearly variation, growing season conditions generally became increasingly hot and dry with time since treatment. Plots were given supplemental water 
during the summer 1996. Snowfall records were set during the winter 1996-1997, and thunderstorms occurred frequently during the summer 1997. These favorable conditions ended with the hot, dry summer 1998. Long-term, regional drought set in with the hot, dry summer 2000 and generally low precipitation throughout 2001. Although 2002 was less dry than the previous 2 years, precipitation was not sufficient to break the long-term drought. Summer (July and August) precipitation at Aneroid Lake (similar elevation and 5-10 km away) was 5.1 and $5.7 \mathrm{~cm}$ in 1996 and 1997. Between 1998 and 2002, it ranged between 0.6 and $2.4 \mathrm{~cm}$.

\section{Results}

Closure and restoration of campsites resulted in a large increase in density of plants established from seed. Despite an original density of virtually zero, mean density of perennial plants was 55 plants $/ \mathrm{m}^{2} 7$ years after closure (Table 1). Throughout the experiment, plants that were seeded were much more abundant than those that volunteered. Fewer woody plants established from seed and survived, despite the dominance of woody plants off-site. Among the herbaceous plants, graminoids were somewhat more abundant than forbs. Density of annuals varied substantially with climatic conditions and whether their remains were still evident at the time of data collection (Table 1). Therefore, only the response of perennials is described in this article. Annuals never provided a substantial portion of the ground cover.

Although closure and restoration increased plant density, density declined greatly with time since treatment (Table 1). During the moist summers 1996 and 1997, many seedlings germinated and established, and there was virtually no mortality during the growing season (Cole \& Spildie 2000). Over-winter survival rates of about $70 \%$ meant that a majority of individuals from both the 1996 and the 1997 cohorts were alive at the start of the 1998 growing season (Cole \& Spildie 2000). During the dry summer 1998, however, few new seedlings established and mortality rates approached 50\%. Density declined more slowly thereafter, until the large decrease in 2002. Although density of seeded perennials declined over the 7 years, density of volunteers did not (Table 1).

Sitanion hystrix did not establish successfully from seed, establishing at low densities on only two of the six seeded plots (Table 2). All the other seeded species established on virtually all plots on which they were seeded. Although their density declined, all seeded species survived after 7 years. The most abundant species in 2002 were Penstemon globosus (seeded on one site), Antennaria alpina (seeded on two sites), and Juncus parryi (seeded on three sites). The most widespread species, occurring on 69 of the 72 plots, was the volunteer, Carex rossii. The only other perennial species to volunteer on more than $15 \%$ of the plots were the seeded species, J. parryi, and three tree species, Abies lasiocarpa (16 plots), Picea engelmannii (15 plots), and Pinus contorta (23 plots).

\section{Effect of Restoration Treatments on Plant Density}

Restoration treatments varied in effectiveness. Scarification substantially increased establishment and survival of plants from seed (Fig. 2). Plant density was significantly greater on plots that were scarified (but not seeded, amended with organics, or mulched) than on control plots that were closed to use but received no restoration treatments (repeated measures ANOVA, $F_{[1,5]}=11.5, p<$ $0.01)$. Seven years after treatment, the density of plants established from seed was more than three times greater on scarified plots than on those that were not scarified. With our experimental design, it was not possible to assess the effect of scarification on sown seed because all planted plots were scarified.

Interactions between the main effects of the threefactor experiment were never statistically significant. Consequently, the main effects of each factor are described separately. Seeding had the most profound effect on seedling density. Magnitude of effect varied significantly with year since seeding (i.e., the interaction between year and seeding was statistically significant, $F_{[6,366]}=7.88, p<$ 0.01), generally declining over time (Fig. 3). Seven years after seeding, in 2002, density was more than five times

Table 1. Plant densities (plants $/ \mathrm{m}^{2}$ ) at the end of each growing season.*

\begin{tabular}{|c|c|c|c|c|c|c|c|}
\hline All perennials & 242 & 246 & 138 & 131 & 96 & 93 & $55(12)$ \\
\hline Seeded perennials & 518 & 502 & 238 & 246 & 177 & 147 & $83(25)$ \\
\hline Perennial graminoids & 137 & 143 & 88 & 87 & 60 & 54 & $29(5)$ \\
\hline Perennial forbs & 96 & 96 & 43 & 41 & 35 & 42 & $23(8)$ \\
\hline Shrubs & 0.1 & 0.3 & 0.9 & 0.7 & 1.0 & 1.0 & $0.6(0)$ \\
\hline
\end{tabular}

* Mean (SE) in 2002 of all plots on all sites, other than the control plot $(n=72)$, except that seeded plant densities were only calculated for those plots that were seeded $(n=30)$. 
Table 2. Mean (SE) plant densities (plants $/ \mathrm{m}^{2}$ ) at the end of each growing season for seeded species and for two species that volunteered on more than $50 \%$ of plots.*

\begin{tabular}{|c|c|c|c|c|c|c|c|}
\hline & 1996 & 1997 & 1998 & 1999 & 2000 & 2001 & 2002 \\
\hline An. lanata-seeded $(n=6)$ & 8 & 24 & 11 & 13 & 12 & 11 & $8(6)$ \\
\hline Danthonia intermedia-seeded $(n=6)$ & 371 & 339 & 111 & 71 & 18 & 19 & $2(1)$ \\
\hline Juncus parryi-seeded $(n=18)$ & 237 & 201 & 134 & 131 & 82 & 68 & $34(10)$ \\
\hline$J$. parryi-volunteer $(n=72)$ & 1 & 2 & 2 & 2 & 2 & 3 & $2(1)$ \\
\hline Sibbaldia procumbens-seeded $(n=12)$ & 28 & 32 & 11 & 6 & 4 & 3 & $2(1)$ \\
\hline Sitanion hystrix - seeded $(n=6)$ & 1 & 1 & 1 & 1 & 1 & 2 & $1(0)$ \\
\hline Carex rossii-volunteer $(n=72)$ & 12 & 20 & 20 & 17 & 13 & 17 & $12(2)$ \\
\hline
\end{tabular}

$* n$ is the number of plots in which the species established. For $J$. parryi, a few of the individuals reported as seeded might have been volunteers.

greater on seeded plots than on plots that were not (ANOVA, $F_{[1,4]}=43.9, p<0.01$ ). Density of volunteer perennials did not vary significantly between plots that were seeded and transplanted and those that were not $\left(\right.$ ANOVA, $\left.F_{[1,4]}=0.02, p=0.86\right)$. Mean density of perennial volunteers on seeded and transplanted plots varied among years, between 19 and 42 plants $/ \mathrm{m}^{2}$. On plots that were neither seeded nor transplanted, density varied between 18 and 41 plants $/ \mathrm{m}^{2}$. One might logically expect either increased success for volunteers on plots with transplants (due to facilitation) or decreased success for volunteers on seeded and transplanted plots (due to competition). Either they offset each other or neither occurred to a significant degree.

Mulching with a biodegradable mat did not have a significant long-term effect on plant density (Fig. 4) (ANOVA, $\left.F_{[1,4]}=1.1, p=0.36\right)$. In the first year after treatment, more perennial volunteers established on the plots that were not mulched (ANOVA, $F_{[1,4]}=4.86, p=$ 0.03 ). Seeded species initially appeared more abundant on plots that were mulched, although differences were not statistically significant (ANOVA, $F_{[1,4]}=0.18, p=0.67$ ).

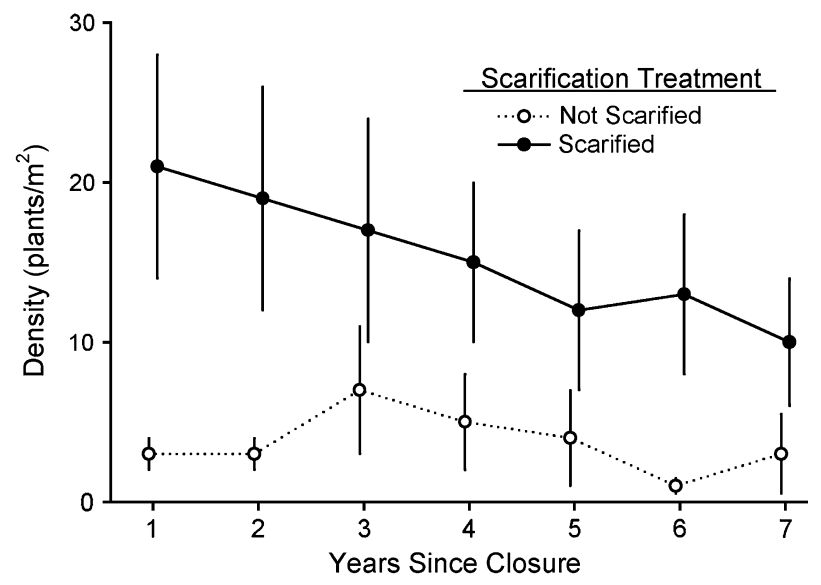

Figure 2. Effect of scarification on plant density ( $\bar{X}$ and SE) on plots that were not seeded.
In the later years, however, after the mulch mat had disintegrated, differences were minimal for both seeded species and volunteers.

Soil amendments were effective over the long term. Again, the repeated measures ANOVA indicated that magnitude of effect varied with year since treatment (i.e., the interaction between year and soil amendment was significant, $\left.F_{[12,366]}=3.36, p<0.01\right)$. In this case, effects were least pronounced in the first years following closure (Fig.5). Seven years after treatment, plant density on plots that received organic amendments was more than twice the density on plots that received no amendments (adjusted Dunnett's multiple comparison, $t[10]=-1.83, p=0.04)$. Plant density on plots that were amended with organics and compost was more than three times the density on plots that were not (Dunnett's $t[10]=-2.50, p=0.01)$. Differences between the two amendment treatments were not statistically significant (adjusted Tukey's multiple comparisons, $t[10]=0.66$, $p=0.40)$.

Effectiveness of soil amendments varied among species. Overall, seeded species, volunteers, graminoids, and forbs

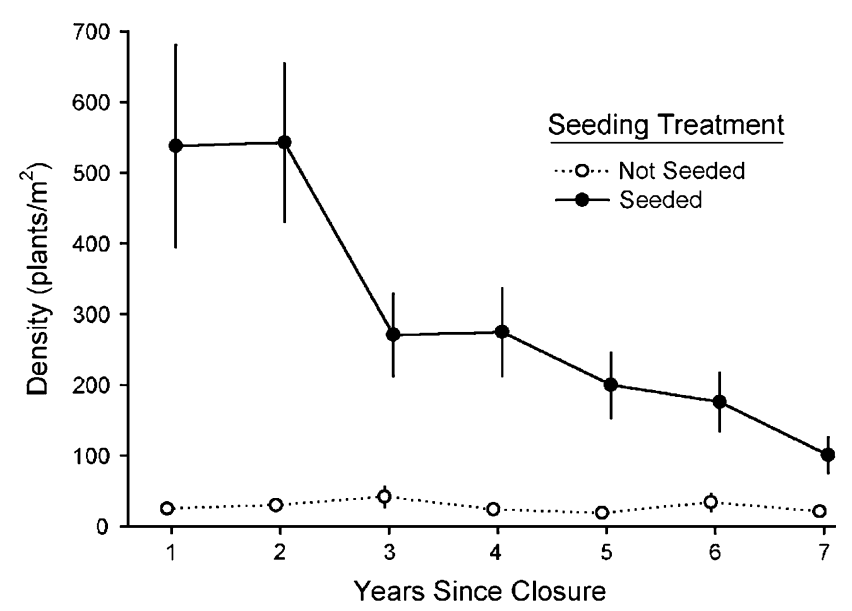

Figure 3. Effect of seeding on plant density ( $\bar{X}$ and SE). 


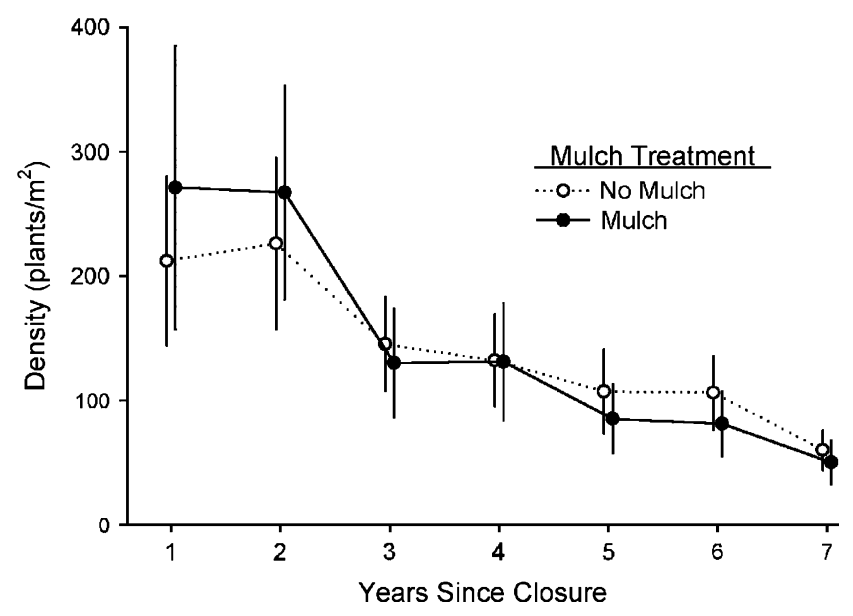

Figure 4. Effect of mulch on plant density ( $\bar{X}$ and SE).

all had higher densities on amended plots than on nonamended plots. Tree seedlings did not have higher densities on amended plots (Table 3). For volunteers, differences among soil treatments were statistically significant, but the response of seeded species was so variable that differences did not meet the 0.05 criterion for statistical significance (Dunnett's $t[10]=-1.57, p=0.13$ for the difference between nonamended and organics and compost plots).

Of the seeded species, An. alpina, An. lanata, J. parryi, and Pe. globosus had higher densities on amended plots, whereas Aster alpigenus, Danthonia intermedia, Phleum alpinum, Sibbaldia procumbens, and S. hystrix did not. Carex rossii, which volunteered, also responded positively to soil amendments. In 2002, mean densities for C. rossii were $5( \pm 2)$ plants $/ \mathrm{m}^{2}$ on nonamended plots, $14( \pm 2)$ plants $/ \mathrm{m}^{2}$ on organics plots, and $17( \pm 3)$ plants $/ \mathrm{m}^{2}$ on organics and compost plots. The difference between nonamended and organics plots was statistically significant (Dunnett's $t[10]=-2.52, p=0.03$ ) as was the difference between nonamended and organics and compost plots (Dunnett's $t[10]=-2.99, p=0.01$ ). For $C$. rossii, the

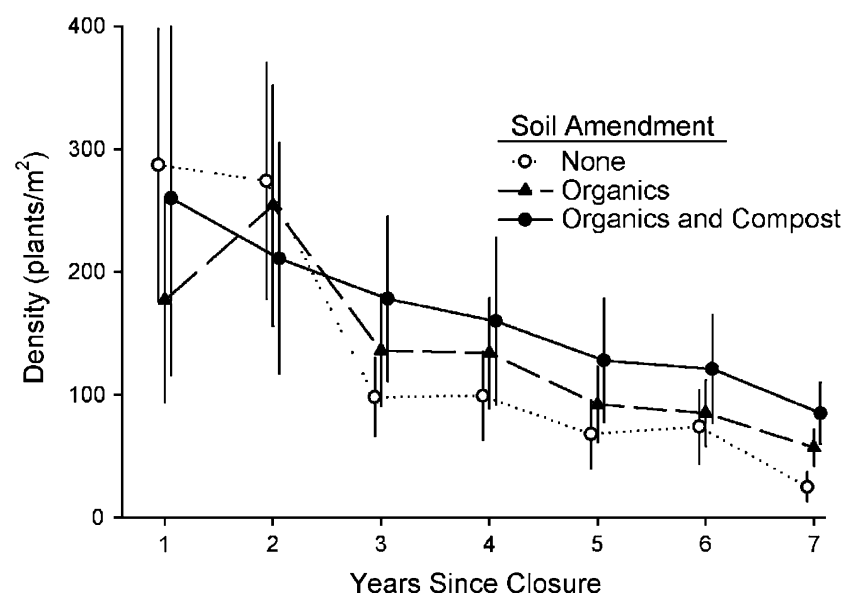

Figure 5. Effect of soil amendments on plant density ( $\bar{X}$ and SE).
Table 3. Mean (SE) plant density in 2002, 7 years after closure, on plots with various soil amendments.

\begin{tabular}{lccc}
\hline & \multicolumn{3}{c}{ Soil Amendment } \\
\cline { 2 - 4 } & None & Organics & Organics and Compost \\
\hline Seeded species & $33(11)$ & $89(42)$ & $127(59)$ \\
Volunteers & $11(3)$ & $19(2)^{*}$ & $32(9)^{*}$ \\
Graminoids & $17(6)$ & $28(7)^{*}$ & $43(11)^{*}$ \\
Forbs & $4(2)$ & $25(16)$ & $40(19)^{*}$ \\
Tree seedlings & $3(1)$ & $2(1)$ & $1(1)$ \\
\hline
\end{tabular}

$n=24$ plots for each soil amendment treatment, except for seeded species, where $n=10$ plots for each treatment.

*Amended plots with significantly higher densities than nonamended plots $(\alpha=0.05)$.

organics appeared to be the critical amendment more than compost.

\section{Effects of Restoration Treatments on Plant Biomass and Height}

Effects of treatments on plant growth were assessed for seeded species ( $P h$. alpinum on three sites and An. alpina and Pe. globosus on one site each). For root and shoot biomass, assessed the first 2 years only, interactions between mulch and soil amendment were not statistically significant. Overall, the mulch treatment had little effect on root or shoot biomass or the root-to-shoot ratio, either in 1996 or in 1997 (Table 4).

Compared to seedlings growing in plots that received no soil amendments, those growing in plots amended with organics and compost had twice the root and shoot biomass in 1996 (Table 4) and more than three times the root and shoot biomass in 1997, differences that were statistically significant (Dunnett's $t[6]=2.33-2.55, p=0.04$ $0.05)$. Root-to-shoot ratios did not differ. Seedlings in plots amended with organics only (no compost) were not significantly different from those in nonamended plots (Dunnett's $t[6]=0.09-1.07, p=0.25-0.70$ ). Differences between the two soil amendments were only statistically significant for shoot biomass in 1997 (Tukey's $t[6]=-2.64$, $p=0.04$ ). The positive effect of the organic and compost treatment on plant biomass was apparent in all three species but was most pronounced for Pe. globosus and least pronounced for An. alpina.

Plant height, the only indicator of plant growth after the first 2 years, responded to treatments in a similar fashion. Interaction between mulch and soil amendment was not statistically significant. Plant height did not vary significantly with mulch treatment (repeated measures ANOVA, $F_{[1,4]}=0.04, p=0.85$ ). Seedlings growing in organics and compost plots were significantly taller than those growing in nonamended plots (repeated measures ANOVA, Dunnett's $t[10]=3.04, p=0.01$ ), whereas those growing in organics plots were not significantly taller than those growing in nonamended plots (repeated measures ANOVA, Dunnett's $t[10]=1.14, p=0.23$ ). Differences between the two soil amendments were not statistically significant (Tukey's $t[10]=-1.62, p=0.15$ ). 
Table 4. Mean (SE) root and shoot biomass of three seeded species on plots with various restoration techniques.

\begin{tabular}{|c|c|c|c|c|c|}
\hline & None & Mulched & None & Organics & Organics and Compost \\
\hline 1996 shoot biomass (mg) & $6.7(1.2)$ & $5.6(1.8)$ & $3.7(1.1)$ & $6.1(1.6)$ & $8.6(2.0)^{*}$ \\
\hline 1996 root-to-shoot ratio (\%) & $48(7)$ & $60(9)$ & $66(12)$ & $44(9)$ & $52(8)$ \\
\hline 1997 root biomass $(\mathrm{mg})$ & $51(16)$ & $70(20)$ & $30(14)$ & $38(3)$ & $112(29)^{*}$ \\
\hline
\end{tabular}

*Amended plots that differed significantly from nonamended plots $(\alpha=0.05)$.

Individual species responded variably, however. Height of An. alpina seedlings increased consistently over the 7 years of the experiment, as did the Pe. globosus seedlings (Fig. 6). Height of Ph. alpinum seedlings peaked 5 years after seeding, declining thereafter. Soil amendments had a greater effect on the two forbs, An. alpina and $P$ e. globosus. For the two forbs, both the organics and the organics and compost treatments had a positive effect on plant height (Fig. 6). For Ph. alpinum, the positive effects of the organics and compost treatment disappeared by 2002 .

\section{Effects of Restoration Treatments on Flowering}

Few plants flowered the first 2 years after treatment. However, by the third year, more plants were flowering (Fig. 7). A larger proportion of plants were flowering in plots that received the organics and compost treatment than in nonamended plots (repeated measures ANOVA, Dunnett's $t[10]=3.07, p=0.01)$. Differences were particularly pronounced in the third, fourth, and fifth years after treatment. The organics-only treatment did not have a positive effect on flowering (repeated measures ANOVA, Dunnett's $t[10]=0.55, p=0.44)$, and this amendment differed significantly from the organics and compost treatment (Tukey's $t[10]=-2.53, p=0.04$ ). Flowering was not enhanced by either the mulch treatment (repeated measures ANOVA, $F_{[1,4]}=0.60, p=0.48$ ) or seeding (repeated measures ANOVA, $\left.F_{[1,4]}=0.36, p=0.58\right)$.

\section{Discussion}

All treatments, except the biodegradable mulch mat, contributed to increased revegetation success. Scarification, organic and compost soil amendments, and seeding all increased plant density. Of these, seeding had the most pronounced effect. Lack of interaction between soil amendments and seeding suggests that each can be successful, but success is greatest when both are combined. Although not tested experimentally, it is likely that seeding would not have been very successful without scarification. Observations suggest that none of these treatments would have been effective without site closure.
Seeding and transplanting (all seeded plots were also transplanted) did not inhibit establishment of volunteers. Volunteers were as abundant on planted plots as on unplanted plots. As reported in Cole and Spildie (2000), spatial analysis of the 1996 cohort indicated that established seedlings were aggregated to a significant degree (rather than being regularly or randomly distributed). Aggregation was greater for seeded species than for volunteers, suggesting that aggregation resulted more from the seeding process than distribution of "safe sites." On planted plots, seedling density was greater outside the canopy of transplants than inside the canopy. However, seedlings were located closer to transplants than expected. This suggests that the most favorable locations for seedling establishment are close to-but not underneathtransplants.

The ineffectiveness of the mulch mat was surprising, as mulching is frequently recommended, particularly on harsh sites (Urbanska 1997; Petersen et al. 2004). The mulch mat also did not increase survival or growth of transplants (Cole \& Spildie 2006). It is possible that our result reflects growing conditions that were unusually favorable for the first two growing seasons. There was virtually no mortality in either 1996 or 1997. By the hot, dry summer 1998, when mortality was high (approximately $50 \%$ ), the mulch mats had largely disappeared. If moisture had been more limiting in those years when the mat was functional, results might have been different.

Increased density on plots with organic and compost amendments likely resulted in large part from the slowrelease fertilization effect of the compost. Analysis of soils on these campsites, 3 years after restoration, showed that organics and compost plots had almost twice the potentially mineralizable $\mathrm{N}$ of unrestored control plots (Zabinski et al. 2002). This may explain the much larger root and shoot biomass and height of plants on organics and compost plots. Soil amendments had no effect on rates of establishment, and as long as growing conditions were favorable, there was no effect on survival and density. However, when moisture became limiting, the larger plants, with better-developed root systems, survived more frequently. In 1998, when there was virtually no summer rainfall, the mortality rate on organics and compost plots was much lower than on other 

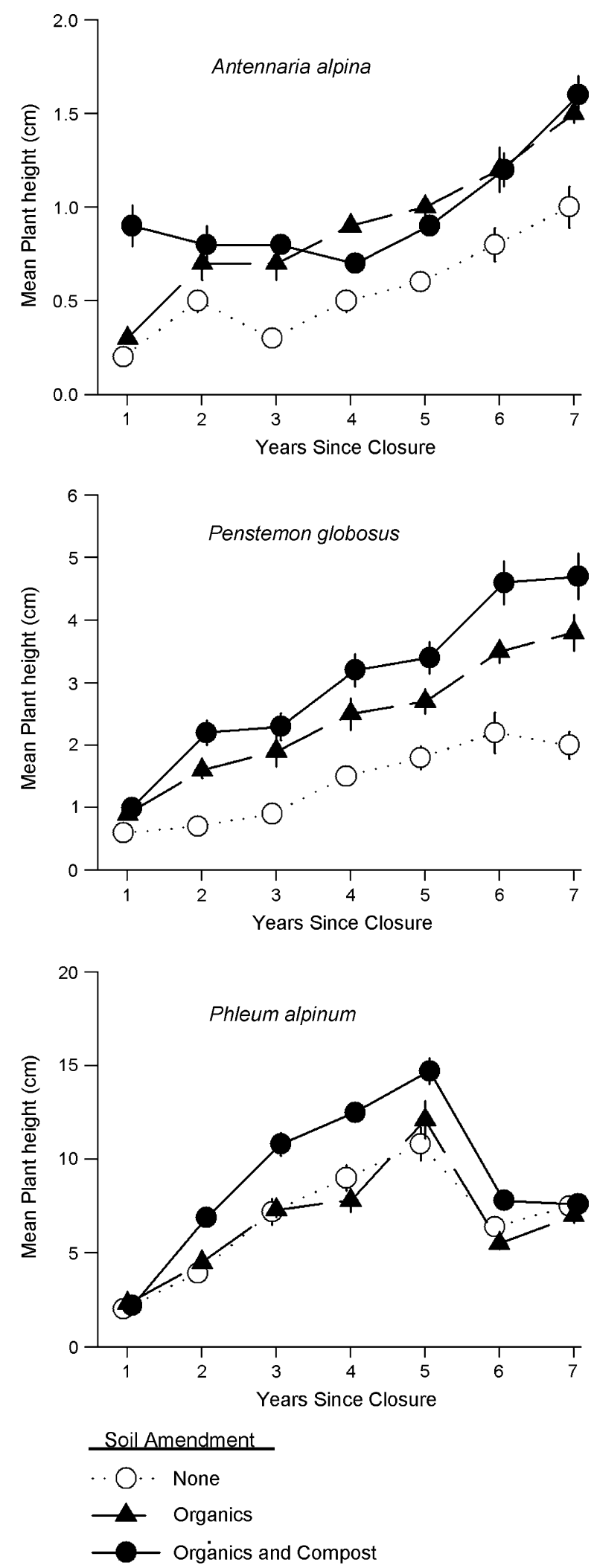

Figure 6. Effect of soil amendments on height of three seeded species ( $\bar{X}$ and SE).

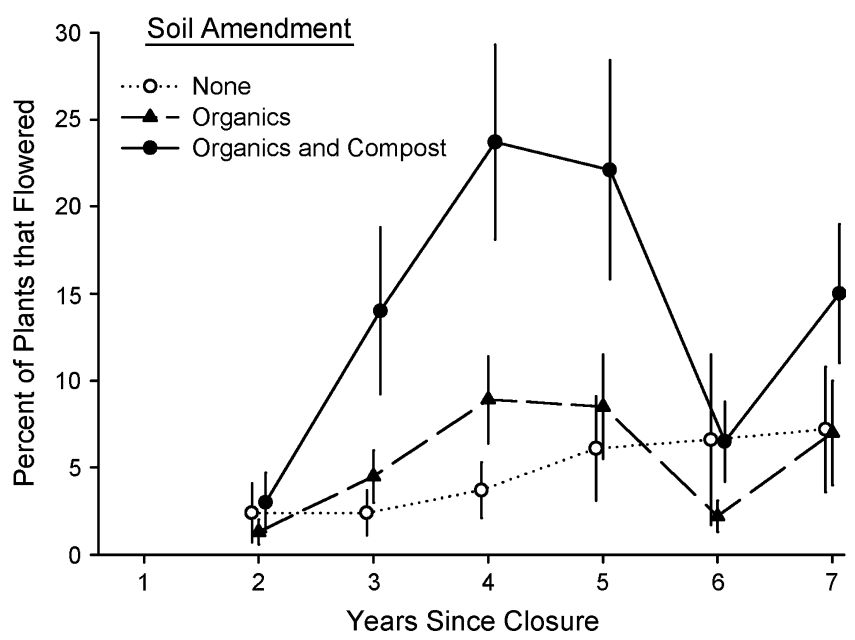

Figure 7. Effect of soil amendments on plant flowering ( $\bar{X}$ and SE).

plots. Thereafter, densities were always higher on organics and compost plots. Plants on organics and compost plots flowered at an earlier age than on other plots, possibly resulting in increased propagule availability on those plots.

The plots amended with organics and soil inoculum (but not compost) had higher densities than nonamended plots, despite plants on those plots not having betterdeveloped root systems or being much larger. This might reflect positive benefits of microbial inoculation or the effects of organic matter in increasing soil water-holding capacity or inhibiting recompaction of soils after scarification. Results regarding positive effects of this treatment on plant height and flowering are less conclusive. Plants on plots amended with organics were intermediate in height and proportion flowering, compared to the other treatments, and not significantly different from either.

Positive effects of organics and compost amendments have been demonstrated in other studies. Amendments increased growth of transplants on these campsites (Cole \& Spildie 2006). Legg et al. (1980) found that incorporation of wood chips into soil on campsites prolonged positive effects of scarification on soil bulk density. Organic amendments have had the positive effects of increasing microbial biomass and activity and promoting revegetation in varied environmental settings (e.g., DeLuca \& Lynch 1997; Ros et al. 2003). Our work demonstrates that these treatments are effective in restoration of recreational disturbances in subalpine ecosystems. Moreover, they can be practically applied even in remote locations, at least to small disturbances such as campsites. It would be worthwhile extending research on organics and compost in campsite restoration to assessments of the effectiveness of different amendment quantities, types, and depths of incorporation into the soil. Organic fertilizers, in combination with locally collected organic matter, might prove convenient for use in remote locations because they are less bulky than compost. Paschke et al. (2000) reported 
that amendments with an organic fertilizer were particularly effective in encouraging plant growth on roadcuts.

Scarification reduces adverse effects of soil compaction, by increasing the volume of macropores, infiltration rates, and aeration, reducing barriers to root penetration, and increasing soil surface heterogeneity, allowing for more abundant seed entrapment and creation of safe sites. On abandoned roads in Grand Teton National Park, Cotts et al. (1991) found that scarification and seeding in combination were twice as effective in increasing plant cover as seeding alone and that scarification alone had no effect. This differs from our finding that scarification alone was beneficial, though not nearly as beneficial as scarification in combination with seeding.

We gave all plots small amounts of supplemental water several times during the first summer following seeding. It is unclear to what degree this increased seedling density, either that year or in subsequent years. Substantial germination and establishment of new seedlings occurred during the second summer, when no supplemental watering occurred.

Our results suggest that restoration of the herbaceous cover on these campsites can occur rapidly using the techniques we employed. All but one of the species we seeded established in substantial quantities and 36 perennial species volunteered on these sites. Although plant density declined greatly over the 7 years, the density of survivors (mean of 55 plants $/ \mathrm{m}^{2}$ ) exceeds that of herbaceous plants in the naturally sparse cover on these sites. The density of Carex rossii, the most abundant herbaceous species in this vegetation type, was 13 plants $/ \mathrm{m}^{2}$ on restored plots, a density comparable to that on undisturbed sites. The remaining challenge to restoration of these campsites is reestablishment of shrub species. The ericaceous dominants, Vaccinium scoparium and Phyllodoce empetriformis, seldom reproduce from seed and are difficult to transplant (Cole \& Spildie 2006).

\section{Implications for Practice}

- In the absence of active restoration treatments, recovery of damaged campsites in these subalpine forests is likely to require many decades, even with effective elimination of recreation use.

- Recovery rates can be accelerated using soil scarification, seeding with local native species, and soil amendments of organic matter and compost.

- Despite the widespread use of mulch blankets for the restoration of recreational disturbance, the straw blankets we used had little effect. Further research is needed to understand the conditions under which mulch blankets are helpful.

- Seeding appears to be an effective means of reestablishing graminoids and forbs on these sites; transplanting will probably be required for the reestablishment of shrubs and trees.

\section{Acknowledgments}

This work was made possible by the field assistance of many, particularly D. Spildie and J. Comstock. I appreciate the assistance in data analysis of $\mathrm{N}$. Christensen and R. King and helpful reviews of C. Monz and T. Hall.

\section{LITERATURE CITED}

Chambers, J. C. 1997. Restoring alpine ecosystems in the western United States: environmental constraints, disturbance characteristics, and restoration success. Pages 161-187 in K. M. Urbanska, N. R. Webb, and P. J. Edwards, editors. Restoration ecology and sustainable development. Cambridge University Press, Cambridge, United Kingdom.

Chambers, J. C., J. A. MacMahon, and R. W. Brown. 1988. Seedling establishment in disturbed alpine ecosystems: implications for revegetation. High Altitude Revegetation Workshop No. 8, Proceedings, Fort Collins, Colorado, 3-4 March 1988. Colorado Resources Research Institute, Fort Collins.

Chambers, J. C., J. A. MacMahon, and R. W. Brown. 1990. Alpine seedling establishment: the influence of disturbance type. Ecology 71:1323-1341.

Cole, D. N., and R. K. Fichtler. 1983. Campsite impact in three western wilderness areas. Environmental Management 7:275288.

Cole, D. N., and D. R. Spildie. 2000. Soil amendments and planting techniques: campsite restoration in the Eagle Cap Wilderness, Oregon. Pages 181-187 in D. N. Cole, S. F. McCool, W. T. Borrie, and J. O'Loughlin, compilers. Wilderness Science in a Time of Change Conference. Proceedings RMRS-P-15_VOL-5. USDA Forest Service, Ogden, Utah.

Cole, D. N., and D. R. Spildie. 2006. Restoration of plant cover in subalpine forests disturbed by camping: success of transplanting. Natural Areas Journal 26:168-178.

Cotts, N. R., E. F. Redente, and R. Schiller. 1991. Restoration methods for abandoned roads at lower elevations in Grand Teton National Park, Wyoming. Arid Soil Research and Rehabilitation 5:235-249.

DeLuca, T. H., and E. L. Lynch. 1997. Assessment of amendments in the reclamation of an abandoned mine in Montana. Intermountain Journal of Sciences 3:38-46.

Hitchcock, C. L., and A. Cronquist. 1973. Flora of the Pacific Northwest. University of Washington Press, Seattle.

Legg, M., K. Farnham, and E. Miller. 1980. Soil restoration on deteriorated campsites in Texas. Southern Journal of Applied Forestry 4:189-193.

Lester, W. J. 1990. Revegetation efforts at North Cascades National Park complex. Pages 261-270 in H. G. Hughes and T. M. Bonnicksen, editors. Restoration '89: the new management challenge. Society for Ecological Restoration, Madison, Wisconsin.

Moritsch, B. J., and P. S. Muir. 1993. Subalpine revegetation in Yosemite National Park, California: changes in vegetation after three years. Natural Areas Journal 13:155-163.

Paschke, M. W., C. DeLeo, and E. F. Redente. 2000. Revegetation of roadcut slopes in Mesa Verde National Park, U.S.A. Restoration Ecology 8:276-282.

Petersen, S. L., B. A. Roundy, and R. M. Bryant. 2004. Revegetation methods for high-elevation roadsides at Bryce Canyon National Park, Utah. Restoration Ecology 12:248-257.

Ros, M., M. T. Hernandez, and C. Garciá. 2003. Soil microbial activity after restoration of a semiarid soil by organic amendments. Soil Biology and Biochemistry 35:463-469. 
Smyth, C. R. 1997. Early succession patterns with a native species seed mix on amended and unamended coal mine spoil in the Rocky Mountains of southeastern British Columbia, Canada. Arctic and Alpine Research 29:184-195.

Urbanska, K. M. 1997. Restoration ecology research above the timberline: colonization of safety islands on a machine-graded alpine ski run. Biodiversity and Conservation 6:1655-1670.
Urbanska, K. M., and M. Schütz. 1986. Reproduction by seed in alpine plants and revegetation research above timberline. Botanica Helvetica 96:43-60.

Zabinski, C. A., T. H. DeLuca, D. N. Cole, and O. S. Moynahan. 2002. Restoration of highly impacted subalpine campsites in the Eagle Cap Wilderness, Oregon. Restoration Ecology 10:275281. 